\title{
Úvodník 2021/XVI/1
}

\author{
Jana Dlouhá \\ Envigogika 16 (1) - Úvodník/Editorial
}

Published/ Publikováno 5. 11. 2021

DOI: $10.14712 / 18023061.631$

Vážení čtenáři, př́iznivci Envigogiky,

$V$ době, kdy pišu tento úvodník, se má na nebi objevit polární záře. Co pamět́ sahá, nikdy předtím tu nebyla. Jenomže co tu dřív nebylo, se ted' ukazuje nepř́ijemně často. Žijeme $\checkmark$ období přechodu a s tím spojených nejistot; čekáme na znamení. Náznak nebo předzvěst toho, co príijde - $v$ dobrém, nebo ve zlém...

Jdeme na noční výpravu. Na nebi hvězdy, jasné, kolem obzorů blednoucí. Mraky jako mléčné dráhy napříč oblohou. A stromy stále těsněji svírající horskou cestičku. Vzduch je nečekaně vlahý, bez trpké príchutě tlení, i přes pozdní podzim. Vystoupáme až na vrchol kopce, jenže i ten je zarostlý stromy. Hledáme průhledy, nic ale nevidíme.

Ráno se ukazuje, že nikdo ( $v$ celých Čechách) taky nic nevidí. Snad možná zítra - přiště.

Naděje napnuté k přišstě - to je zkušenost posledních let a ted' už desetiletí. Nenechat si ukrást budoucnost, to jsme se zatím nenaučili. I když je věda docela účinnou obranou proti manipulaci, neumí popsat to, co by být mohlo. Co bychom měli teprve uskutečnit ... a tak zkoumáme terén nejistoty a hledáme orientační body. Znamení. Jak dobré může být to, co je zatím zcela neznámé? Musíme se rozhodovat, i když nevíme.

Také naši autoři osahávají terén neznámého: toho, co můžeme jen (ze své perspektivy) zakoušet. Lukáš Nekolný na príkladu proměn zoologických zahrad ukazuje, jak se vyvijí vztah člověka a (divokého) zvířete - mění se koncept, na němž jsou založeny, a následně i jejich vnější podoba. Původně měla tato zařizení symbolizovat lidskou moc nad př́rodou, předvádět její „živé exponáty"; teprve postupně přechází k ochraně druhů a tzv. edutainmentu. Tuto vzdělávací roli zoo ovšem problematizuje Marie Hrdá: z výsledků mezinárodních výzkumů vyplývá nejednoznačnost dopadu na environmentální cítění, hodnoty a postoje návštěvníků, i jejich znalosti o prírodě. Pokud se ale na přínosy zoo podíváme z etického hlediska, vidíme ale další možné okruhy jejich vlivu. Rozpor mezi těmito dvěma názory na (ne)přijatelnost "věznění" divokých zviŕat, jakkoli je morálně odůvodněné, ovšem může být jen zdánlivý - zmizel by, pokud by zoo byly jen ukázkou divočiny, nikoli jejích posledním útočištěm. Což je posun, k němuž dochází a přispiváme $\mathrm{k}$ němu i my, svými stále stoupajícími nároky.

Životní styl obyvatel planety začíná být totiž ve svém součtu neudržitelný. Hrozí, že lidská rozpínavost pohltí poslední zbytky přírody a jejích původních mimo-lidských obyvatel. Zabránit tomuto vývoji by asi mohla změna systému (to zatím nevíme), drobně přispět $k$ ní ale může i každý z nás. Vědomá, odpovědně rozmýšlená volba spotřební strategie je jedním ze způsobů, jak nepř́znivý stav řešit na individuální úrovni. My všichni jsme spotřebitelé, stejně jako jsme i občany, a to, jak (společně) naplňujeme tyto dvě role, teprve formuje ekonomický a politický systém. Úloha vzdělávání je tak zásadní pro utváření příští podoby 
světa (bohužel vzdělávací systém tuto naši každodennost s velkým dopadem na jeho stav systematicky opomíjí). Jak kultivovat spotřební chování směrem k šetrnosti, naznačují dva články tohoto čísla: Vzdělání k udržitelné spotřebě a životnímu stylu... představuje širší souvislosti a teoretické základy, což doplňuje druhý text - navrhuje, jak odpovědné chování rozvíjet v praxi, např́klad i s využitím podkladových materiálů pro učitele $k$ tomu vytvořených. Podobné úvahy bývá užitečné rozšírit o perspektivu třetího světa; co se týče odpadních plastů (vedlejšího produktu spotřeby), zvažuje Loveth Aikowe možnosti (a limity) environmentální vzdělávání na vysokoškolské úrovni v Nigérii. Jde o zemi, kde jednotlivci musí být hlavními činiteli žádoucích změn, protože systém často nefunguje (což této zkušenosti zajišt́uje platnost celkem obecnou). $\mathrm{K}$ debatě o udržitelných zvyklostech $v$ oblasti stravování a produkce potravin přispívá i text kolektivu autorů z Jihočeské univerzity - zkoumají, na čem je založena pěstitelská gramotnost u žáků na druhém stupni základních škol.

Vědomá změna hodnot a zvyklostí je ale pouze jedním ze způsobů, jak působit na podobu (naší společné) budoucnosti. Tato budoucnost totiž už dávno není to, co bývala - pouhým prodloužením, extrapolací pozitivních aspektů současnosti dosáhneme spíše nebývalého nárůstu jejích nepříznivých dopadů. Osvícenější část populace hledá a zkouší alternativy, a presto vzděláváme stále pro svět, který zde je nebo spiše byl v (poněkud idealizované) době minulé. Jak rozvíjet představy o budoucnosti, a podpořit jedince, aby potřebné změny uskutečnili, se dozvíte $v$ článku mapujícím základní předpoklady vzdělávání pro budoucnost - je především souhrnem celosvětových debat na toto téma.

K přemýšlení o budoucnosti patři ovšem i zamyšlení nad tím, co bylo: $v$ tomto čísle Envigogiky diskutuje o roli médií při formování (po)vědomí o environmentálních problémech a podpoře kritického myšlení, i o jejich historické podobě na Slovensku prof. Mikuláš Huba.

Naplnit naděje na dobrý život $v$ budoucnosti, když přitom minulost nemá být zapomenuta ani zavržena, bude těžké, musíme se o to ale soustavně pokoušet. Dělejte to $s$ námi, jednou $z$ cest je - psát (a učit) o něčem, co by mohlo být, ale zatím není.

Hodně přiležitostí k zamyšlení (a prípadně i čas na sepsání Vašich myšlenek)

Vám přeje za Envigogiku

Jana a Jirka Dlouzí 